\title{
ESTUDIOS
}

\section{Virtuosismo en Juan del Valle y Caviedes}

EDUARDO HOPKINS RODRIGUEZ

\section{El Virtuosismo en el Barroco}

En lo que se refiere a los autores y a los géneros, las manifestaciones del virtuosismo literario en el Barroco se hallan tanto en el nivel culto como en el nivel popular. De otro lado, el ejercicio de formas cultas y populares es usual en escritores de formación más o menos erudita como Góngora y Quevedo. Lope aspiró también al doble dominio de los estilos. Caviedes, un autodidacta de modesto cultivo y en quien predominan las formas populares, luce su afición por lo culto en sus composiciones religiosas, en el poema "A la muerte del maestro Baes" (RI75)', en otros textos de tono serio y hasta en sus burlas mitológicas.

Con referencia al carácter virtuosista de la época barroca Vossler decía:

"El virtuosismon poétiebl en tiempe de Lope se manifestaba en tres amplios campos literarios: existía un virtuosismo humanista, latinista o italianizante que gustaba de la improvisación y del ornato de la poesía erudita de género bucólico, arcádico y académico; había un virtuosismo juglaresco como el del autor de romances; y existía también el virtuosismo del escritor que improvisaba y escribía a vuela pluma comedias en verso"1a

El mismo autor, hablando de la fruición artística en el Barroco, señalaba:

${ }^{1}$ A continuación de las citas de textos de Caviedes se indica simplemente el número de página correspondiente a la edición de Vargas Ugarte. Cuando las referencias sean tomadas de la edición de Odriozola se antecederá la página con una $\mathrm{O}$, y con una R si se trata de la publicación de poesías inéditas hecha por Reedy.

1a Karl Vossler, Escritores y poetas de España, p. 73. 
"De una parte el aumento de la habilidad artística desarrolla una pompa y profusión de formas para ensalzar la autoridad del Estado, de la Iglesia, de la Sociedad, incluso de la Majestad de Dios y de la naturaleza, en suma, para reverenciar y lisonjear al poder. Pero, por otra parte, se produce un lujo igualmente desmesurado del querer y poder artísticos sin servicio cortesano alguno, exclusivamente en solicitud y glorificación de la fantasía, es decir, de la pura magia de la fantasía"²

La "extrañeza" barroca ${ }^{3}$, uno de los motores del virtuosismo, era el ideal estilístico de la época. Casalduero considera como el "gran honor del Barroco" el que se tuviera a las obras como singulares, raras, extrañas, admirables". "Maravillarse y hacer que las gentes se maravillaran fue el programa consciente de la poética barroca (...)" ${ }^{\text {" }}$. Si hacemos presente la opinión que tenía Gracián de Marino, a quien comparaba entusiastamente con Góngora como hombre de ingenio ${ }^{6}$, comprenderemos el valor sui generis que poseen los siguientes versos de una cita sobre el poeta italiano tomada de Hocke: "E del poeta il fin la meraviglia./Chi non sa far stupir vada alla striglia'. Lo maravilloso, pues, lo 'prodigioso', es el fin del arte y, quien no sepa provocar estupor, "bien hará en irse de mozo de cuadra." ${ }^{6 a}$ Concepción de la que, en esencia, ya participaba Tasso ${ }^{7}$. Esta "maravilla" buscada por el virtuosismo es equivalente del afán ilusionista que invade a las artes en general, claramente bbservableenla plâstica $\$$ en la escenificación teatral. En literatura celgespectáculbi Gaptifieroso" se informa malabarísticamente abarcando lo puramente gráfico de la escritura, la

${ }^{2}$ Karl Vossler, La Soledad en la Poesía Española, p. 137.

${ }^{3}$ Joaquín Casalduero, Estudios sobre el teatro español, p. 153.

${ }^{4}$ Ibidem. p. 158.

${ }^{5}$ Vossler, Escritores cit., p. 121.

6 "El Góngora de Italia, el culto Marino (...)." Baltazar Gracián, Agudeza y arte de ingenio, Disc. XVI.

${ }^{6 a}$ Gustav René Hocke, El Manierismo en el arte europeo, p. 26.

7 "(...) la tesis fundamental de la poética de Marino, el principio de que la poesía ha de sorprender y asombrar, tiene su origen en Tasso, quien afirmaba ya que la mentira es más poética que la verdad, y que lo maravilloso, en el sentido de lo engañoso, consituye el objeto en sentido propio del poeta". Arnold Hauser, El manierismo. La crisis del renacimiento y los orígenes del arte moderno, p. 328. 
organización sintáctica de las frases, el juego fonético de los vocablos, las falacias, los enigmas, los trucos de versificación, etc. La composición general del todo, creado con este sentido del trucaje, del juego, de la dispersión de lo cotidiano y la diversión por el "engaño", era algo tácitamente convenido entre productor y consumidor, y, tal vez, exigido por la voracidad ilusionística del público barroco.

En arte y literatura poseemos un término de la época sumamente expresivo, por su extensión y uso, respecto de la actitud vital de entonces: Ingenio. Apartado del intelectual exclusivismo manierista, se populariza en el Barroco y, como un sexto sentido, prolifera en todos los estratos sociales y actividades. Nos vemos ante un "furor ingenii", "un prurito de individualismo y originalidad ingeniosa".

"En la relación del individuo consigo mismo y con los de su profesión, este enaltecimiento origina aquel empeño egocéntrico de agradar y de contemplarse que se manifiesta en innumerables polémicas y envidias literarias, intrigas y escritos burlescos, y no en ứtimo término en la difamadora murmuración; las desagradables huellas de este áspero combate no se hallan precisamente en la lectura de las obras literarias, sino al estudiar la vida y las relaciones personales de los distintos autores. En cambio, en la relación del individuo con la multitud, aquẹl leriąhtecimiente prōduce pos un lado el soberano desprecio de la masa y del rulgo necio por otro el dominio espiritual de lă multitud que nadie supo ejercer en la práctica como Lope de Vega y su teatro."

En cuanto al concepto de ingenio, recién en la época barroca se va estableciendo con claridad, separando otras acepciones que corresponden a funciones o potencias del alma diversas, para ceñirse a lo que se denominaba fuerza de entendimiento:

"Si lo desligamos por una parte de la fórmula estrictamente filosófica y consideramos por otra su relación semántica con la

${ }^{8}$ Ludwig Pfandl, Historia de la Literatura Nacional Española en la Edad de Oro, p. 263.

${ }^{9}$ Ibidem. pp. 263-264.

Recordemos que en los escritos burlescos de Caviedes, se destaca la inclinación satírica hacia personas identificables históricamente, tanto médicos como poetas rivales, aunque tal identificación no siempre haya sido posible. 
palabra poeta, [el término ingenio desplaza al término poeta] veremos que ingenio equivale a aquella refinada espiritualidad que reúne en sí misma la fuerza, la osadía y la agilidad de inteligencia, la finura de la gracia, la agudeza de la ironía, el juicioso examen de las flaquezas de los demás, la prontitud de la réplica y el buen gusto.(...) Este concepto del ingenio no es el orgullo del Renacimiento humanista, sino el del talento arbitrariamente barroco, basado en sí mismo". ${ }^{10}$

La realización más alta del ingenio es la agudeza, el concepto. Para Gracían, ${ }^{11}$ de las cuatro causas que atribuye a la agudeza, el ingenio es la principal. Y encuentra en el concepto que "es este ser uno de aquellos que son más conocidos a bulto, y menos a precisión; déjase percibir, no definir; y en tan remoto asunto, estímese cualquiera descripción; lo que es para los ojos la hermosura, y para los oídos la consonancia, eso es para el entendimiento el concepto". ${ }^{12}$ Sin embargo, poco después se arriesga con una definición de indubitable importancia para la poética barroca, y que, al decir de Lázaro Carreter ${ }^{13}$, no parece haber sido sustancialmente interpretada. Afirma Gracián:

"Es un acto del entendimiento, que exprime la correspondencia que se halla entre los objetos.(...)

Esta correspondencia es genérica a todos los conceptos, y abraza todo el artificio del ingenio, que aunque éste sea tal vez por contraposicion y disonancia, aquello mismo es artificiosa conexión de los objetos".14

${ }^{10}$ Pfandl, Historia cit., p. 265.

${ }^{11}$ Agudeza cit., Disc. LXIII.

12 Ibidem. Disc. II.

${ }^{13}$ Fernando Lázaro, Estilo Barroco y Personalidad Creadora, p. 14.

${ }^{14}$ Agudeza cit., Disc. II. "La jerarquía tradicional, integrada por un centro poético circuido de una serie de elementos subordinados, que contribuyen a darnos un conocimiento directo del mismo, se rompe en la estética expuesta por Gracián. Se trata ahora de tender puentes entre ese centro y otros lugares más o menos lejanos, se trata de conocer el objeto, no en sí, no por descripciones que nos conduzcan hacia él, sino por las relaciones que el poeta ha tendido. El escritor nos niega la visión directa de su objeto y nos fuerza a contemplar su imagen en otra u otras cosas. La visión directa ha quedado sustituída por una visión refleja". Lázaro, Estilo Barroco cit., p. 15. 
Tales correspondencias habrán de ser exploradas y expresadas por los ingenios como prueba de su talento. A su vez, la dificultad producida por estas relaciones a descifrarse encarecerá la fruición estética del consumidor.

Centrándonos en la producción literaria de España en el siglo XVII, hemos de encontrar un amplísimo catálogo de técnicas de la agudeza cuyos antecedentes han sido rastreados por Curtius hasta la época alejandrina, se continúan en la Edad Media Latina y tienen "su último brote en el siglo XVII", siendo su lugar de mayor arraigo en esta época el suelo español, precisamente. ${ }^{15}$

Gracián sistematiza estas técnicas, y nos deja "una 'suma' de la agudeza". ${ }^{16}$ Aunque sin ceñimos estricta ni exclusivamente, tomamos como punto de referencia su ya citado libro, para indagar en el texto de Caviedes y ofrecer una exposición de recursos que haga evidente su aprecio por el ingenio, su actitud virtuosista. ${ }^{17}$

\section{El ingenio}

El sentido de ingenio posee plena conciencia en Caviedes; lo trata directamente o alude a él tan sólo. En muchos lugares la pura mención de la palabra ingenio u otras conexas con ésta descubre el interés que el poeta proplondiona adlâ actitudarital de la época.

\section{«Jorge Puccinelli Converso»}

${ }^{15}$ Ernst Robert Curtius, Literatura Europea y Edad Media Latina, Tomo I, p. 384 y ss., especialmente p. 409.

"No es difícil hallar en las épocas más variadas rastros de la técnica, que, con rigor, podemos llamar conceptista. Pero esos rastros pasan a primer plano y se acumulan en los umbrales del siglo XVII. Efectivamente, un ansia febril, casi demoníaca, de confundirlo todo, de urdir y tramar las cosas más heterogéneas, parece invadir a cuantas mentes discurren por esa época". Lázaro, Estilo Barroco cit., p. 16.

${ }^{16}$ Curtius, Literatura Europea cit., Tomo 1, p. 422.

${ }^{17}$ Es probable que Caviedes haya leído Agudeza y arte de Ingenio -publicada ya en 1642 - sin embargo no pensamos que su vinculacion con este libro sea directa. Creemos que los dos autores toman sus recursos del material que la época les proporciona. Antes y después de Agudeza la literatura española del Barroco se ha nutrido de las fórmulas de ingenio que registra Gracián. Sin excluir la posible directa influencia del libro en cuestión, consideramos que nuestro poeta se forma a partir de un corpus literario y no de uno teórico. Quevedo sería, por ejemplo, uno de esos modelos, con quien la crítica ha conseguido anotar relaciones textuales en la obra de Caviedes. 
En su "Carta que escribió el autor a la monja de México"...(32), desde el título encontramos que la llama "el mayor ingenio de estos siglos", y en el cuerpo del poema existen 11 menciones a "ingenio" y derivados, 8 a "entendimiento", 4 a "discreción" y 1 a "agudeza". En otras composiciones se observa:

$\begin{array}{ll}\text { ingenio: } & \text { 36-39-110-139-154-165-167-168-194-206- } \\ & \text { 213-217-229-235-243-285-313-321-331- } \\ & \text { R177-R178-R179, etc. } \\ \text { entendimiento: } & \text { 38-72-96-99-101-106-110-139-168-189- } \\ & \text { 260-313-324-R176-R177-R178, etc. } \\ \text { agudeza: } & 313-315-319-R 176, \text { etc. } \\ \text { discreción: } & 38-39-73-182-211-212-289-291-324-R 176- \\ & \text { R177-R178, etc. } \\ \text { concepto: } & 38-129-139-148-149-168-189-200-230, \text { etc. }\end{array}$

Como puede notarse, los puntos de acumulación de estos términos llevan en común el tratar asuntos que tienen que ver sustancialmente con el ingenio: El primero, es el poema a la monja de México, todo un cúmulo de conceptos a la inteligencia. El segundo, dedicado al virrey Conde de Monclova (36) con motivo de un poema suyo: Caviedes se ocupälde laś condicionesedel: “ejercicio" de poeta y de lo que significa serlo. Eb siguiente,]1 "Ada muerte del maestro Baes" (R175), es un elogio hiperbólico a un intelectual. El cuarto, "Doctos de chafalonía" (138), satiriza a los doctos de apariencia. El quinto, es un romance "A uno que preciaba mucho de poeta, ..." (167). El último (312), referido a la ignorancia de los médicos, idea que el poeta apoya con numerosas citas de "ingenios".

Caviedes se consideraba un ingenio, y -aparte de las actitudes adoptadas en sus poemas, que bastan para patentizar sus inclinaciones- lo expresa ostensiblemente en varias ocasiones: (subrayamos nosotros)
"en el mar de vuestro ingenio
veo lo que el mío alcanza
y en lo poco que percibo
conozco lo que me falta"(33) 
"Sólo la razón ha sido

doctísima Salamanca,

que entró dentro de mi ingenio

ya que él no ha entrado en sus aulas"(34)

"correis con aqueste aplauso

la pelota de aclamada

y nadie os la vuelve, porque

todos quisieran hurtarla

y así os la vuelvo, porque

no llego a necesitarla,

pues en pelota está quien

desnudo de ingenio se halla"(35)

"porque en dando ser poeta

os consideran vestido

como a mí y otros ingenios

de andrajos del Baratillo"(36)

"Cuatro contras que ha de tener el entendido

para serlo.

Contra médicos es tódo entendido, contra vulgo y sus falsas opiniones, contra hipobritas quales santulones;

y contraJlar gstrologia sil ha anentido"(106)

(Por supuesto que el poeta reúne estos "requisitos")

"Dos veces para mí santo

es Agustino discreto:

una, por contra doctores

otra por santo estupendo".(212)

Este último caso tiene una forma paralela en el siguiente:

"pues no es poeta el que no

satirizare aforismos"; (40)

Lo mismo en:

" $y$ en fin no hay hombre ingenioso

que a esta profesión defienda". (321) 
"Héme criado entre peñas de minas, para mí avaras, mas ¿cuándo no se complican venas de ingenio y de plata?".(34)

"A mi prima machucaste, Machuca y ya que la ofensa ha sido contra mi sangre, la he de vengar con mi vena" (261)

"que siempre ha sido colirio

a todo mal un discreto". (289)

(Se refiere a sus sátiras contra médicos).

"En burlas y veras trata

de los médicos mi vena;" (322)

También las alabanzas al ingenio, al entendimiento, a lo discreto, son atendidas por Caviedes, tanto graciosamente como en forma de verdadera preocupación. Así, acompañando a la belleza femenina, la cual se ve realzada:
"Cuando a lo hermoso acompaña
lo entendido, el amor flecha
como Parcabuz de das qtios, etras
con arcorde dóscsaeels; Converso"
la discreción viene a ser
una hermosura compuesta
de voces que los oídos
la ven con ojos de idea;" (72-73)

(Una concepción semejante, aunque no tan complicada, nos la da Gracián tratando del concepto: "lo que es para los ojos la hermosura, y para los oídos la consonancia, eso es para el entendimiento el concepto".) ${ }^{18}$

$$
\begin{aligned}
& \text { "quien lo discreto no ama } \\
& \text { de irracional ser se precia," (73) }
\end{aligned}
$$

${ }^{18}$ Agudeza cit., Disc. II. 
"Manda que toda discreta

y linda pida un millón,

que en la discreción no puede

ser un ciego [cupido] el tasador". (182)

Se encarece lo discreto por compensación o por ausencia:

"por una fea y discreta

soltura y prisión padezco,

pues quanto me suelta el rostro

me prende el entendimiento":, (324)

"Por una tonta y hermosa

neutral estoy padeciendo,

pues quanto en el ver me agrado

en el oir me atormento", (324)

Un elogio a la "monja de México":

"corridos teneis los hombres,

porque venceis su arrogancia,

amazona de discretos,

con diestras agudas armas". (35)

Para una muestra del valor que ha entregado al ingenio, ya en tratamiento más serio que los anteriores:

“(...), el que usa del talento,

que anda elevado en cosas superiores

y el oro y plata no andan en el viento,

discursos halla, coplas y aun amores,

de esto enriquece el pobre entendimiento,

vestido y sustentado de primores"

(Soneto "Razón...") (101)

“(...) el que tuviere entendimiento

el más feliz será que hay en el suelo".

(Soneto "Que no...") (110)

Quizás donde pueda resaltar enérgicamente su amor a esa "fuerza de entendimiento" sea en la oposición, satírica o no, frente a su medio: 
"porque anda en esta tierra

lo racional muy perdido,

muy ajado lo discreto

y lo ingenioso malquisto" (39)

"que hay mucho oído y poca inteligencia;

por lo cual yo colijo

que el ingenioso Lope atento dijo:

'oiréis la campana en el oído

que parece conceptos y es sonido',

en la gente de enjalma

que sorda y ciega tiene siempre el alma"; (139)

"El es hombre de oropel,

que con ingenio de talco

lo que es rebuzno en -su voz,

concepto es para lo asnos". (168)

Dentro de este mismo cariz de confrontación con la necedad circundante, Caviedes alcanza a precisar un rasgo esencial del ingenio barroco; la arbitrariedad. El poeta efectúa una intransigente distinción entre "hacer letras" y "estudiar letras", probablemente en acción contra el sistema memorístico vigente en la educación colonial, la pedantería erudita, la đẹpendenctacespecto de läsastoridades académicas tradicionales o contra la esterilidad intelectuabnutrida en el hurto a los autores de mérito: (Subrayamos)

"Definicion de lo que es ciencia"

"Esta voz letras dice entendimiento, no el tener muchos libros de memoria, que esta locuaz, inútil vanagloria, afectada hermosura de talento.

Papagayos de imprenta, hombres de cuento, atados a la letra y a la historia, pregoneros de otros, cuya gloria charlatanes usurpan en su aumento. El discurso es principio de la ciencia, a quien muchos inhábiles injurian, 
porque todos son voz sin suficiencia

y así digo, porque éstos se concluyan,

que unos hacen las letras en ciencia

y otros, simples como ellos, las estudian" (99)

"Hombres de letras entienden

que son los que se desvelan

en saberlas de memoria,

y es errada inteligencia;

porque letras significa

entendimiento, agudeza

de ingenio, $y$ hay quien las tiene

aunque el ABC no sepa". (313) 293).

(Para otros casos con puntos de vista similares véase: 139-260.

Es este orgullo del ingenio, ostentoso de originalidad y desdén para la general tontería, el que desencadena un sentido arbitrario del intelecto. Volviendo a un texto ya citado, se decía: "Este concepto del ingenio no es el orgullo del saber del Renacimiento humanista, sino el del talento arbitrariamente barroco, basado en si mismo" ${ }^{19}$.

Desde otro ángulo, las frecuentes alusiones a la necedad de la gente, a su ignorancia, al “Qulgo-imperito’exponen su aprecio por la "discreción", de igualombdBuquénsusi frecuentes" burlas a los poetas malos.

\section{3. 'El autor 'vive' dentro de su obra'}

El epígrafe citado corresponde a Guillermo Díaz Plaja ${ }^{20}$, y se trata de uno de sus 17 elementos del barroquismo. La contrapartida clasicista sería: "El autor se sitúa 'fuera de su obra""21

Los momentos en los cuales Caviedes infiltra su presencia en los poemas resultan ser predominantemente de tono burlesco; las intromisiones del autor en los textos se convierten en fórmulas de

${ }^{19}$ Pfandl, Historia cit., p. 265.

${ }^{20}$ Hacia un concepto de la literatura española, p. 19.

${ }^{21}$ Ibidem. p. 18. 
comicidad o ironía. Conviene precisar que no estamos aludiendo a una primera persona, soporte del discurso y evidentemente incluida como factor de composición. Se trata de indicios de "autor", por los que se llama la atención hacia el artífice como entidad extrapoética, sin que, como se verá más adelante, aquellos indicios sean ajenos a la obra.

Las muestras primeras se producen en juegos conceptuosos que relacionan cualesquiera objetos con términos técnicos oficio de versificación ${ }^{22}$ :

Dilogía con materiales de construcción:

"Ya mi voz en tanta obra

la considero embarazo,

dando con mi canto ripio

adonde sobran los cantos".(45)

"Señor, Sol, Febo ú Apolo,

no me dé ripio a la máno

con sus nombres, que esto es

de ingenios de cal y canto". (117)

"Quedaos con êl y con vos

que ya dejo de cantaros,

que en iglesia de madera

están ociosos los cantos". (243)

Dilogía con partes anatómicas:

"Con poético rigor

candente tu pie se estrecha,

haciendo versos de endecha

para ser de arte mayor.

Descalzo estará mejor,

pues no gasta pundonores

un pie que por más primores

22 "El empleo metafórico de los términos gramaticales y retóricos procede del sistema escolar de la tardía Antigüedad y de la Edad Media". "Como tantas otras cosas, también esta curiosidad estilística pasó al manierismo español del siglo xvı". Curtius, Literatura Europea cit., Tomo I1, pp. 591-592. 
desdalzo tiene que andar,

si el calzarlo es quebrantar

la regla de los menores". (186)

(Se trata de "una dama que se ajustaba los pies" con el fin de hacerlos hermosos por su "brevedad".).

Dilogía con enfermedad estomacal:

"Romance alevoso a las seguidillas de una dama" (Título) (0129).

"A un poeta que de hacer versos le dieron seguidillas". (Título) (0137)

Indicaciones de la forma estrófica o métrica usada:

"Discúlpame, mi Inesiya

el retrato, que al pintaye

aun no osará retocaye

mi beyaca redondiya". (196)

"Dejo, dejando esto a un lado,

finalmente, como digo,

que también tienen los muertos

en el hablar estrivillos". (220-221)

"Aviendo salido estos versos respondió a ellos con unas décimas puercas elPr. Corcobado y unos esdrújulos tan derechos como él. A que se le respondió en los mismos metros". (Subtítulo) (235)

"decimos y redecimos,

$y$ volvemos a decir

treinta mil veces y cinco,

que para dar asonante

basta ajustarlo de pico": (263)

"En la ciudad de los Reyes

dicho mes y día dichos,

porque también hay en verso

abreviaturas de ripios," (283) 
Reflejo sobre la escritura

"Quédate para chiquito

que ya de escribir me canso,

pues para tan corto asunto

hay mucho versificado". (173)

(El poema se titula "Habiéndose graduado de doctor un abogado muy pequeño y flaco, escribió el autor este romance".)

Comentario sobre la cualidad de los versos empleados:

"Perdonad de este romance

el ser puerco por servicio

que á ser puerco y muerto no

lo aplaudiérais de cochino.

$Y$ pues gustais del humor

Vuestro, yo gusto del mío;

que tengo cursos de versos

y de ellos estoy ahito.

Estos sucios me inspiraron

los ingenios pocos limpios

de una Elvira Musa y un

Apolo Vásquez su hijo". (0131)

"No son caprichos mis versos", (315)

Los juegos con tales términos implican virtuosismo desde el punto de vista del conocimiento que el autor pretende poseer de su oficio, cuya exposición realiza, por esta vez, ingenuamente.

Mayor grado de artificio adquiere la imposición del creador en el texto de "Polifemo y Galatea". Las llamadas de atención inciden ahora sobre la técnica narrativa. tarla":

Ha entrado Galatea y el poeta interrumpe la acción para "retra-

"Pero ¿cómo, sin copiarla, por menor su beldad saco?

Corto el hilo de la entrada

que después volveré a atarlo". (120) 
Luego otra detención, a través de un enunciado excusa, que se refiere a las descripciones hechas sobre Polifemo y la ninfa. Nada más que un pretexto para un "jugoso" concepto y para mostrarnos su técnica:

$$
\begin{aligned}
& \text { "Medio jayán, media ninfa } \\
& \text { copio no más, por juntarlos } \\
& \text { y hacer novedad de un } \\
& \text { hermafrodita retrato". } \\
& (120-121)
\end{aligned}
$$

(Lo que aduce Caviedes para justificar el concepto "-hacer novedad"- nos lleva a recordar lo dicho páginas antes sobre la extrañeza barroca y la finalidad del arte de entonces).

"Vuelvo al hilo de la entrada

y así prosigo anudândo" (121)

Con este se retoma el "hilo" de la acción.

"Sosegóse la pendencia

porque entre todas pensaron,

lo que diré en otra copla

que en esta no cabe tanto".(123)

Esta vez, además de atiaer qa mirada sobre la factura del texto, crea un recurso burlón dé suspenso nafrativor so"

"Dejemos estos amores

de los dos, y doy un tranco

para hablar de Polifemo

que estaba dado á los diablos". (125)

El ir y venir de la visión creadora es remarcado en estos versos. Lo de "tranco" juega con el gigantismo de los personajes y el cambio de situación. Es una reproducción de la fórmula "capítulos trancos" de Vélez de Guevara en El Diablo Cojuelo, aunque en éste parece aludirse a la cojera del protagonista. ${ }^{22 a}$.

${ }^{22 a} \mathrm{Si}$ esto bien presenta analogías con ciertas fórmulas de la litertura medieval, debemos reiterar que los juegos del virtuosismo barroco suelen tener sus orígenes en dicha época. Véase p. 9 y nota (15). 
Esas señalaciones, o ese mostrar la técnica del texto, sus junturas, sus lazos, sus figuras, denotan el placer del virtuoso cuyo arte no está sólo en la mera creación de una "obra", sino en que tal "obra" rompa sus límites tradicionales y "coquetee" con sus secretos. Vemos la ilusión creada y el rompimiento de esa ilusión por el discurso entrometido del poeta. La obra es ahora como una pintura en la que aparecen no sólo sus motivos propios sino también el pintor y sus instrumentos como protagonistas camuflados. ${ }^{23}$

Esto bien puede ser un estereotipo, definible como la supremacía del virtuoso sobre su creación. Queda a un lado el apriori aristotélico del ocultamiento de la técnica y del artificio en la presentación de la obra concluida. El sentido tradicional que implica el citado apiori produce una creación parcial, insuficiente para la nueva época. El hombre barroco suele ser un escéptico desmixtificador; no basta para él una arista del objeto, tiene que multiplicar para conocer. La multiplicación cognoscitiva frente al objeto se manifiesta en el arte como sobreexpresión -no en sentido peyorativo- por la cual se aglomeran los medios de comunicación artística: "De acuerdo con cl sentimiento barroco, toda obra artística es el resultado de la unión de diversas artes". ${ }^{24}$

La revelación de la interioridad de la naturaleza humana era una actividad intensa en ta cultura de los siglos XVI y xVII, marcada en su predilección por el minucioso fetrato íntimo, afluencia que se posesio-

${ }^{23}$ Salvando distancias y diferencias respecto a Caviedes, tal es la idea que Spitzer propone para Cervantes y el Quijote: "En estos pasajes Cervantes destruye a sabiendas la ilusión artística: él, que mueve los títeres, nos permite ver los hilos con que los mueve, como diciéndonos: 'mira, lector, esto no es la vida; esto es sólo ficción, novela, en una palabra, arte: reconoce el poder vivificador del artista como algo distinto de la vida.' " "Muy por encima de este su vastísimo cosmos de su creación, en el que se combinan y entremezclan cientos de personajes, situaciones, perspectivas, acciones principales y secundarias, tiene su asiento el yo artístico de Cervantes, un yo creador y omnipotente, natural y deiforme, omnipresente, omnisciente, rebosante de bondad y comprensión. Y este creador que en todas partes vemos, nos revela los secretos de su creación, nos muestra la obra de arte en su gestación y las leyes a que necesariamente ha de someterse. (...) el artista Cervantes ha ensanchado, (...), la independencia demiúrgica, casi cósmica del artista". Leo Spitzer, Lingǘstica e Historia Literaria, p. 219 y ps. 223/224/225.

Nos interesa acentuar aquí la actitud virtuosista de Cervantes.

${ }^{24}$ Pfandl, Historia cit., p. 270. 
na de la plástica, de la poesía y demás concreciones culturales, atribuyendo a la condición humana el eje de sus goces y tormentos. ${ }^{25} \mathrm{El}$ interés, la necesidad de revelar el entramado interior de la personalidad humana iban paralelos a una particular estimación de la individualidad en su poder creador, que llega a tomar como florescencia al orgulloso concepto del ingenio. La capacidad de ser ingenio parasita al antes mencionado escepticismo desmixtificador y refleja al virtuoso, glorificándolo; el creador discurre contemplándose en la obra de arte. Es Narciso en el Barroco. ${ }^{26}$

${ }^{25}$ Dilthey analiza en la época del Renacimiento y de la Reforma las nuevas inclinaciones vitales de la cultura: "El reflejo filosófico de todo este movimiento lo tenemos en una amplia producción literaria: su objero es el hombre, la condicionalidad fisiológica de la vida anímica, el poder de las pasiones, los temperamentos, la diversidad de los caracteres de individuos y pueblos, la fisiognómica y todo el conjunto de medios que ayudan a conocer los caracteres $y$, finalmente, las consecuencias que para la conducta de la vida se desprenden de este conocimiento del hombre: se refieren al comportamiento, comprensión y trato de otros hombres y a la determinación del fin moral de la vida". "En la época que consideramos el nuevo arte y la nueva poesía se desarrollan en la atmósfera de esa literatura amplísima que se ocupa del hombre y de su vida". Wilhelm Dilthey, Hombre y mundo en los siglos $x V l$ y XVII, p. 405 y p. 428.

Por su parte, Hauser indica: "Aun cuando la creación de tipos como Don Quijote, Fausto o Hamleo no tiene-mucho que ver con la obsrvación exacta y el estudio técnico de la vida anímica, no deja de ser interesante, sin embargo, que la época en que aquellos fuerongcondebidos, lepfesentár las (la) vez, el comienzo de la moderna psicología como ciencia. (...) En esta época del capitalismo incipiente, de la nueva política realista y de la propaganda religiosa radical, tanto el éxito económico y político como la misma praxis vital, orientada a la habilidad y a la capacidad de concurrencia, presuponían agudeza psicológica, conocimiento seguro de los hombres y la facultad de compenetrarse con las más diversas disposiciones animicas." Hauser, Manierismo cit., p. 339.

${ }^{26}$ Vossler descubre la contradicción existente en Gracián, que enfrenta, por ejemplo, un contenido pesimista con el artificio de la composición, la cual ha sido tan pulida que evidencia el uso de la idea la preferentemente como tema literario. En esto hallamos una forma de manifestarse el virtuosismo, más clara cuanto el propio Vossler remarca la actitud optimista del autor a través del presiosismo estilístico de sus trabajos y a través de las concepciones expuestas en diversas partes de sus escritos; actitud insinuada también, agregaríamos, por su labor erudita. Karl Vossler, Introducción a la Literatura Española del Siglo de Oto, ps. 119-120.

En otro libro, Vossler, hablando de Góngora, introduce la afirmación siguiente acerca del virtuosismo: "El objeto sólo es propuesto -así sucede en todo verdadero virtuoso- como una prueba de capacidad, como un 'tema"'. Lope de Vega y su tiempo, p. 115. 
Se ha ironizado un mito, el de Polifemo, para dar uno nuevo: el del artífice. Aún no basta al poeta lo mostrado. Su producto será no solamente la obra y la presencia protagónica de su elaboración unimismadas como todo artístico, sino que habrá de incluir en este "colectivismo estético" un posible ser de otra manera. ${ }^{27}$ Lo que es burla, chocarrería, ironización, está en manos del artista el continuar siéndolo. Unos cuantos versos, en el instante que enlaza la tradición bucólica a la leyenda homérica del mito de Polifemo, nos darán los destellos del diseño posible: el modo cultista.

"Echó al bastidor un risco,

el cerrojo de alabastro,

$y$ en la chapa de una losa

cerró con llave de mármol".(126)

Luego, cuatro versos ostentosos del imperio de la voluntad creadora hacen el retorno a la forma propuesta, sostenida hasta finalizar mucho después. Estos son los versos:

"Mas ¿qué es lo que dices, Musa?

¿No adviertes que nos burlamos?

Veras reclama el asunto

y dá ląs muestras del paño", (126) 28

La quintilla finalg galiéndasę ldeb tópico del cansancio ${ }^{29}$, concluye irónicamente con un elaborado concepto, aunque ha afirmado

${ }^{27}$ Entre otros casos de "colectivismo estético", Pfandl cita el de la mezcla de estilos. Historia cit., p. 271.

${ }^{28}$ Dámaso Alonso da cuenta de un poema de Quevedo publicado con el tírulo "Búrlase de todo estilo afectado" por Gonzáles de Salas en la Musa VI; para nosotros es un caso paralelo al que acabamos de examinar en Caviedes. Consiste en un ejercicio virtuosista a través de la alternancia intencional y declarada de tres estilos: "(...), empieza, en el que llama 'estilo primero', con todos los tópicos del conceptismo trovadoresco (...).

Luego elige ('estilo segundo') '... el estilo que brilla/ en la culterana prosa,/ grecizante y latinosa' (...)

En fin, decide hablar 'prosa fregona/ que en las orejas se encaje' y comienza en el 'estilo tercero' (...)." Poesía Española, p. 551 y ss., en nota 91.

29 "El motivo más natural para poner fin a un poema era en la Edad Media el cansancio. (...) algunas veces [el poeta] pretende que la Musa se ha fatigado; otras, que él tiene los pies cansados". Curtius, Literatura Europea cit., Tomo 1, p. 137. 
carecer ya de ellos. No existe tal cansancio sino la autosuficiencia del virtuoso que decide terminar por propio albedrío, no por ausencia de conceptos:

$$
\begin{aligned}
& \text { "Aquí la Musa impaciente } \\
& \text { conceptos me niega avara, } \\
& \text { pues no los hallo al presente, } \\
& \text { por un ojo de la cara } \\
& \text { para un ojo de la frente". (129) }
\end{aligned}
$$

Un reflejo en escala menor de estos signos de autor lo tenemos cuando Caviedes anuncia los cambios de tono, de metro, el paso de una estrofa a otra, alguna dificultad retórica o decisión, etc., que introduce en el desarrollo de un poema.

Variación de tono:

"Permitid, beldad discreta, que os hable un rato de chanza, porque es ser necio dos veces el necio que en veras habla" (35)

"Pero vuélvome a las burlas

que hablar contigo de veras

es mucho aprecio, y parece

que salgo de la materia"; (260-261)

Variación de metro:

"Y porque mires, doctor,

que lo que te digo es cierto;

las hazañas de los doctos

oye, mudando de metro". (226)

Paso de estrofa:

"Lo que diré en otra copla que en esta no cabe tanto".

"y así en físicas cadencias

cantaré, en su idiota aplauso,

lo que diré en otra copla

que en ésta no cabe tanto". (248). 
Comentario sobre una "dificultad" retórica:

"era la nariz, (aquí

todo el Parnaso me valga,

si el mismo Apolo tropieza

en las narices más chatas)", (147-148)

Decisiones:

"las manos de cera virgen

eran porque el cristal canta,

que he de hacer cera y pabilo

todo concepto de blancas". (148)

"Lo que el retrato encubría,

colores imaginarias

la retraten, porque desto

mis pinceles se retractan". (148)

(Este último caso es una fórmula de "decoro" que Caviedes acostumbra emplear en sus descripciones, "pinturas", "copias" o "retratos" femeninos).

"en lo que tocà a explicar

de aqueste amor la eficacia etras

en Júpiter, paso, porque

no hay conceptos con que entrarla". (149)

"Sol le llamaba a la sombra, complicación temeraria

y disparate, que yo

lo sustentaré en su cara". (198)

"La hermosura de la ninfa

no me es posible copiarla, porque solo tengo sombras

y los colores me faltan". (199)

Un aspecto más que tendríamos que contemplar consiste en la exhibición del autor a consecuencia de las interrupciones producidas para criticar ciertos modos de cristalización retórica, criticismo 
acorde con la tendencia general a "rectificar lugares comunes de la retórica entonces vigente". ${ }^{30}$ :

"cuando a lo hermoso acompaña

lo entendido, el amor flecha

como arcabuz de dos tiros,

con arco de dos saetas"; (72-73)

"lloraba tan gruesas perlas

como unos huevos de pato,

que aljófares en giganta

dirán que es menudo llanto".

"Tenía en las cejas dos

escopetas apuntadas,

que el matar con flechas y arcos

es muerte de coplas rancias.

Salgamos ya de un Amor

con arco, harpones y aljabas

y tengamos un cupido

con mosquete y bala rasa". (147)

"Al mismo cupido pudo

mostrarle dientes airada,

muelas, colmilitos $y$ eneias Letras

coral y" "pertas Rengastaelli Converso"

que esta beldad no se pinta

como otra ninfa ordinaria,

que me han de deber las muelas

y encías que en coplas andan". (148)

"era el pie de punto y medio,

que por ser ya cosa usada

lo de un punto, quiero yo

echarle a su horma una larga". (148)

Finalmente, quisiéramos acotar que la preferencia de Caviedes para declarar su presencia en el interior del texto se centraliza en sus fábulas burlescas de "Polifemo y Galatea" y "Júpiter e Io". En "Narciso

${ }^{30}$ José María de Cossío, Fábulas Mitológicas en España, p. 684. 
y Eco", de tratamiento mas bien afectuoso por el mito, no abundan las expresiones abruptas de autor, salvo un par de casos (198-199), ya señalados. Este género de fábulas implica un intenso proceso disolutivo de temas poéticos estériles, agotados para la época.

\section{Hipérbatos}

A nivel sintáctico, es éste uno de los rasgos fundamentales del virtuosismo literario culto ${ }^{30 \mathrm{a}}$, en cuya base tenemos un intento de distinción entre la lengua hablada y la escrita -dualidad especial del latín, a la que, al parecer, se trata de $l$ legar ${ }^{31}$; esta dualidad tiene signos de una diversidad social: lo culto, lo aristocrático, distante de lo vulgar, lo popular. En la literatura del xvil, el hipérbaton es uno de los fundamentos de separación entre dos modos de creación artística: un arte comunicativamente restringido, culto, y un arte masivo, dado al "vulgo necio". Aparte de este carácter diferencial del hipérbaton, debemos anotar que por su potencialidad expresiva abre zonas a un virtuosismo preciosista de Ta organizacion formal. ${ }^{32}$

En Caviedes, los hipérbatos son escasos y la mayoría provienen de necesidades tales como elnúmero de sílabas requerido y/o la rima. En este sentido, el hipérbaton se convierte en una licencia métrica. A pesar de ello, las formas empleadas sugieren por su elaboración un

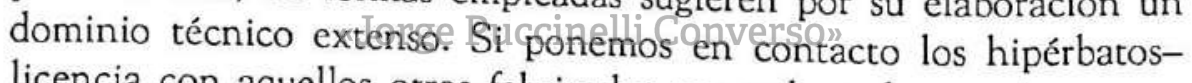
licencia con aquellos otros fabricados por voluntad expresiva, recogeremos el detalle del virtuoso que prueba su capacidad y al mismo tiempo desdeña al instrumento, lo domestica reduciéndolo a una humilde labor auxiliar.

${ }^{30}$ Es el "cultismo sintáctico de la lengua gongorina" "más debatido en las discusiones gongóricas". Dámaso Alonso, La Lengua Poética de Góngora, p. 177.

${ }^{31}$ Ibidem, pp. 181-182.

${ }^{32}$ Dámaso Alonso, por ejemplo, dice de la expresividad del hipérbaton en Góngora: "(...) fue en sus manos un instrumento apto que, en muchas ocasiones, sirve para dar flexibilidad y soltura a la lengua, permite el aéreo encadenamiento de un período, aquí facilita un donaire o una momentánea alusión, allá un efecto imitativo, a veces hace resaltar el valor eufónico o colorista de una palabra, permitiendo su colocación en un punto donde el ritmo tiene su cima de intensidad, otras hace surgir nítido, de punta en blanco, un espléndido verso". Ibidem, pp. 190-191. 
Es indispensable, para comprender esta actitud del poeta, hacerse cargo de las discusiones suscitadas por Góngora al acumular en sus obras mayores lo que para unos eran excelencias del hipérbaton y para otros mero oscurantismo. Más cerca de Caviedes, geográfica y temporalmente, tal polémica es resucitada por un peruano epígono del gongorismo, Juan de Espinoza Medrano, en su Apologético/ En favor de D. Luis de Góngora,/... (1662), una de la mejores defensas del gongorismo, al decir de Dámaso Alonso. ${ }^{33}$ Este crítico subraya la importancia de Medrano en cuanto expositor del valor expresivo del hipérbaton, "desconocido por la crítica de los siglos XVIII y XIX". ${ }^{34}$ "La obra del Lunarejo, tanto su defensa de Góngora, como su colección de sermones, señalan el triunfo del culteranismo y la incipiencia del conceptismo, oficialmente reconocidos como tales, en la literatura del Perú" ${ }^{35}$ La domesticación del hipérbaton o el desdén por éste, es la relegación de un elemento al queluna atmósfera de culteranismo triunfante ha supervalorado. Caviedes, en este caso del hipérbaton, se declara opuesto a la tendencia vigente oficial o académica, a la adhesión culterana colonial. Así nos revela una actitud de virtuosismo autosuficiente, que hace resaltar su no alineamiento dentro del sector del barroco académico, aristocrático, para ublicarse dentro de un barroco popular.

El antiacademicisino deteaviedes aparece demostrado en otra actitud, cuando entreǵa sự coloquiio de "El Portugués y Bachán" (40), dos mendigos limeños, al certamen universitario a la entrada del virrey don Melchor de Portocarrero, conde de la Monclova, en 1689. Juan María Gutiérrez ${ }^{36}$ ha sido de los primeros en comentar la diferencia entre el sencillo ofrecimiento de Caviedes y la culta oración panegírica del catedrático de Prima de leyes doctor don Diego Montero del Aguila. No pensamos, sin embargo, en la carencia de formación cultural de nuestro poeta como factor determinante en esta contraposición estilística, ni tampoco en la "buena índole de su juicio",

\footnotetext{
${ }^{33}$ Góngora y el Polifemo, Vol. I, 244.

${ }^{34}$ Lengua Poética cit., p. 191.

${ }^{35}$ Luis Alberto Sánchez, La Literatura Peruana, Tomo II, p. 476.

${ }^{36}$ Escritores Coloniales Americanos, p. 279 y ss.
} 
explicaciones ambas sostenidas por el crítico argentino ${ }^{37}$, sino mas bien, en su afán virtuosista. Un hombre sin escuela, huérfano de un alto concepto de sí mismo no se atrevería a competir con los doctores universitarios. Estos, en la Edad de Oro española suelen ser motivo de agresión por parte de los ingenios no letrados. El propio Caviedes escribe contra los memoriones eruditos y los satiriza directamente. La ironía de presentarse en "humildes" conceptos al certamen académico, no deja de sugerir la pose atrevida del ingenio -que también en otra ocasión ha escrito un romance panegírico, pero de pretenciones cultas: "A la muerte del maestro Baes"-

Para tener una perspectiva del manejo del hipérbaton en Caviedes, a continuación damos una muestra. ${ }^{38}$ (Van marcados con una $\mathrm{x}$ aquellos hipérbatos que no son licencia métrica). (Subrayamos):

Separación del adjetivo y del sustantivo correspondiente:

"Vos atado y vuestro rostro

de villana mano herido" (1)

$x$ "sacrilegio el más atroz

que se ha contado en los siglos" (2)

"mágicos te eternen cánticos" (10)

"tanto amoricon los hombres infinito" (28)

"segoviana ostentaba argenteria". (95)

"Y porque el carro pase proceloso". (103)

"un bocado de riscos poderoso". (103)

"Si de la espuma naces procelosa" (103)

"que siempre reflección fue venenosa" (106)

"qué máquina postró tan poderosa". (106)

"doscientos le habrán de dar

azotes, (...) (234)

x "con voces de ciencia mudas" (292)

${ }^{37}$ Ibidem. pp. 278-278.

${ }^{38}$ En general, seguimos el inventario de hipérbatos propuesto por Dámaso Alonso en su Lengua Poética cit. p. 182 y ss. No hemos tomado en cuenta alteraciones del orden sintácrico permisibles por el español en cuanto al sujeto, verbo y complementos. Ibidem. p. 208. 
"Anteposición del genitivo y, en general, de toda palabra introducida por de, con respecto al vocablo de que depende":

"de vuestras penas motivo", (5)

"yo de la ignorancia abismo". (6)

"el que fué de pecados un abismo". (24)

"blande del noto a la furia". (80)

"trepan del muro a la altura". (81)

"de vanidad la quimera," (87)

"De Arquitectura escollo y valiente" (102)

"el orgullo del sur, que rompe undoso

del freno de las playas la cadena" (102)

"tu bolsa del oro encierro", (207)

"Un verbo se interpone entre la palabra introducida por de y el vocablo introductor de la preposición":

"¿adónde de sus prestezas

tuvo el polvorín activg?" (2)

"(...), del empíreo

aun excede la belleza?" (85)

(En estos casos hay además una anteposición del genitivo).

"Que había vaguácos dijo

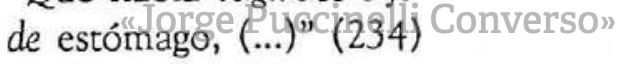

"Vaguidos quieres de estómago", (234)

"que al lucero la pegan

también del alba". (332)

"Cuando un sustantivo tiene dos adjetivos atributos, uno va antepuesto y el otro pospuesto":

"El Padre en su inmenso ser

e infinitamente raro", (11)

"Dos sujetos o dos complementos o predicados van separados por el verbo":

"mis culpas mueran y locos apetitos", (23)

"Rico me hicisteis, noble y estimado", (25) 
"Separación del sustantivo con relación a sus determinativos este, tanto, cuanto aquel, etc.":

"que este tan debido afecto" (17)

"a cuantos de hacerlos tratan

hermanos, (...)," (35)

"Tened siete que otros tantos

tiene la semana días" (167)

Orden de la frase alterado:

"No hiere el harpón tanto

que se dispara cerca", (72)

$x$ "(...), no veneren

humana ya criatura". (82)

Interposición de cláusula en una enumeración de adjetivos:

"iO juicios del cielo, inescrutables, donde el mayor saber es ignorancia, tan extremos, tan raros y admirables!" (25)

\section{Zeugmas}

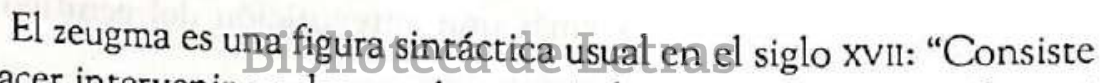
en hacer intervenir en dos o más enunciados un término que sólo está expresado en uno de ellos: extrañó ella que un varón discreto viniese, no ya solo, mas sí tanto (Gracián)"39. Fernando Lázaro distingue entre el zeugma que evita la repetición del termino por "economía de vocablos", normal en el habla, y el zeugma dilógico, propio del XVII, en el cual la palabra en cuestión interviene con distintos significados. ${ }^{40}$ Vossler lo define: "puente o yugo de conjunción entre dos sentidos congregados en un solo término"; y da como ejemplo de este tipo de zeugma el de Dorotea en el Quijote ( $\mathrm{I}, \mathrm{XXVIII})$ : “(Fernando) apretóme más entre sus brazos, de los cuales jamás me había dejado, y con esto, y con volverse a salir del aposento mi doncella, yo dejé de serlo"41.

${ }^{39}$ Fernando Lázaro Carreter, Diccionario de términos filológicos.

${ }^{40}$ Lázaro, Estilo Barroco cit., pp. 33-34.

${ }^{41}$ Vossler, Introducción cit., p. 37. 
Como propone Lázaro ${ }^{42}$, el zeugma dilógico se puede tomar como un "concepto", según la ya tratada definción de Gracián.

Otro caso de zeugma se origina cuando la alusión al término propuesto se hace a través del pronombre: "Este tipo de zeugma es muy antiguo: aparece en la sintaxis impresionista de Mío Cid (...) y surge en el Lazarillo y en Santa Teresa; pero desde fines del siglo XVI su empleo intencionado es manifiesto y abundante; $(\ldots)^{m 43}$.

También existe una distinción entre "zeugma simple, en el cual la palabra no expresada es la misma que figura en el enunciado en que aparece (...) y zeugma compuesto, en que la palabra necesitaría alguna variación morfológica, si fuera expresada (su tono era grave,y sus gestos grandilocuentes) $)^{m 44}$.

Finalmente, los zeugmas se denominan prozeugma o protozeugma, mesozeugma o hipożeugma, según la ubicación del término expreso en la primera oraciôn, en la central o en la final, respectivamente $\mathrm{e}^{45}$.

Para el Siglo de Oro Vossler cree ver las motivaciones de esta figura en la falta de gana y paciencia, vergüenza, bizarría y capricho, familiaridad, prisa, y descuido, demasía de entusiasmo y pasión ${ }^{46}$. Pensamos que es posible ver también el zeugma en su matiz de recurso virtuosista que buscab sorprendef, aextranar,tapelando a la agilidad comprensiva de los destinatariosinexigiéndólés superar la ingeniosa dificultad de hallar lo no expresado. La fórmula producida se hace huella del ingenio, estimula, hace presente la imagen del creador.

De las formas encontradas en Caviedes tenemos un predominio de zeugmas pronominales, ya sean simples, compuestos, con dilogía o sin ella. A pesar del gusto de Caviedes por la proliferación de juegos dilógicos no tenemos un porcentaje de tales zeugmas que supere a los menos complejos, pronominales. Así, entre 25 casos registrados sólo 7 son dilógicos. Citamos algunos ejemplos:

\footnotetext{
${ }^{42}$ Lázaro, Estilo Barroco cit., p. 35.

${ }^{43}$ Rafael Lapesa, Historia de la lengua española, p. 218.

${ }^{44}$ Lázaro, Diccionario cit.

${ }^{45}$ Ibidem.

${ }^{46}$ Vossler, Introducción cit., p. 39.
} 
(Subrayamos).

"¿qué culpa tuvo la que

original no ha tenido", (4)

"Bachán dijo: Compañero,

el temblor, si bien repasas

los cuartos, cual monedero,

rebajó en Lima las casas

y subió los del carnero"(41).

(esta es una forma de zeugma dilógico)

"Con mil almas le decía

a la que sin ella estaba": (64)

"Con esperanzas muertas,

ni aun el mayor aguardo,

porque los daños huyen

de quien busca remedios en los daños".(78)

"para darse las manos a él to alzaron

y también a ta novia la agraviaron,

por ser la del noyio tan pequeña

no pudiendo abarcar la de la dueña", (162)

"Bravo cinujanotace de Letras

el mismo que es grise eliganaverso"

en lo cirujano, que

en lo otro no, que es de casta". (249)

"Los que mataban en Lima

quedarón ya castigados,

España con la victoria

y la Hacienda Real sin gastos". (250)

"Salgan los presos

a juicio en la causa

de no tenerlo". (323)

Otros ejemplos en: $17-17-19-23-24-27-27 / 28-52-53-53-61-65$ -

67-69-73-172-217-316. 


\section{Sustantivos Adjetivados}

La adjetivación de sustantivos es recurso preferido por Quevedo en sus "atrevimientos sintácticos": juez mercadería, hombres crepúsculos (mulatos), clérigo cerbatana, etc ${ }^{47}$. Probablemente sea ésta una de las fórmulas de estilo recogidas por Caviedes en el satírico madrileño. Dámaso Alonso considera este rasgo en Quevedo como un modo de condensación idiomática, por supresión de nexos y formas gramaticales de uso normalizado ${ }^{48}$. En nuestro poeta, representa un proceso por el que el tertium comparationis, el detalle, la cualidad, lo característico, etc., se esencializan en el objeto. No se trata de una modificación adjetiva, que permite conservar la identidad del objeto, sino de una transformación del todo en lo accesorio, de una definición en hipérbole ${ }^{49}$. El juego virtuosista explora la cosa o sujeto, halla el rasgo típico y ejerce la metamorfosis definitoria. Lo acumulativo de las composiciones en Caviedes ${ }^{50}$ también es observable en estos sustantivos acoplados que, a su vez, pueden formar series acumulativas de apodos, como en (273). Los motivos de agresión a través de tales fórmulas resaltan en el área de médicos, boticarios, curaciones, enfermedades:

(Subrayamos):

"nariz de sábado quimera" (105)

(Se trata de un tipo de hipérbaton licencia, "Nariz" es el sustantivo al que se acopla el término adjetivado "quimera").

"mozuelo siete palmos". (118)
"pastorcillo renacuajo". (122)
"novio camote", (159)
"maridillo cinco cuartas", (160)
"giba novio" (162)

${ }^{47}$ Lapesa, Historia cit., p. 228.

${ }^{48}$ Poesía Española cit., p. 529.

${ }^{49} \mathrm{~A}$ esta concepción de los sustantivos adjetivados parece aproximarse Susana Frentzel B. cuando, hablando de Quevedo, dice: “ (...) el licenciado Cabra 'era un clérigo cerbatana' - y no es ya comparación, sino definición de la figura por el objeto, (...)". "Ejemplaridad de la figura humana en 'Los Sueños' de Quevedo". En: El sueño y su representación en el Barroco español, por Dinko Cvitanovic y otros, p. 148.

${ }^{50}$ Vid. parágrafo 16 de este artículo. 
"marido giba" (162)

"era novia, en fin, tan atalaya" (162)

"versos galeotes" (168)

(Juega con "forzado", en doble sentido).

"Licenciado tanto cuanto" (170)

"yegua hilo" (190)

"novio cernicalo" (210)

"doctor peligro" (220)

"doctor don Tabardillo" (223)

"licenciado Modorra" (223)

"Doctor don Terciana" (225)

"licenciado Venenos" (225)

"bachiller nemini parco" (225)

(Traducción: "a nadie perdono")

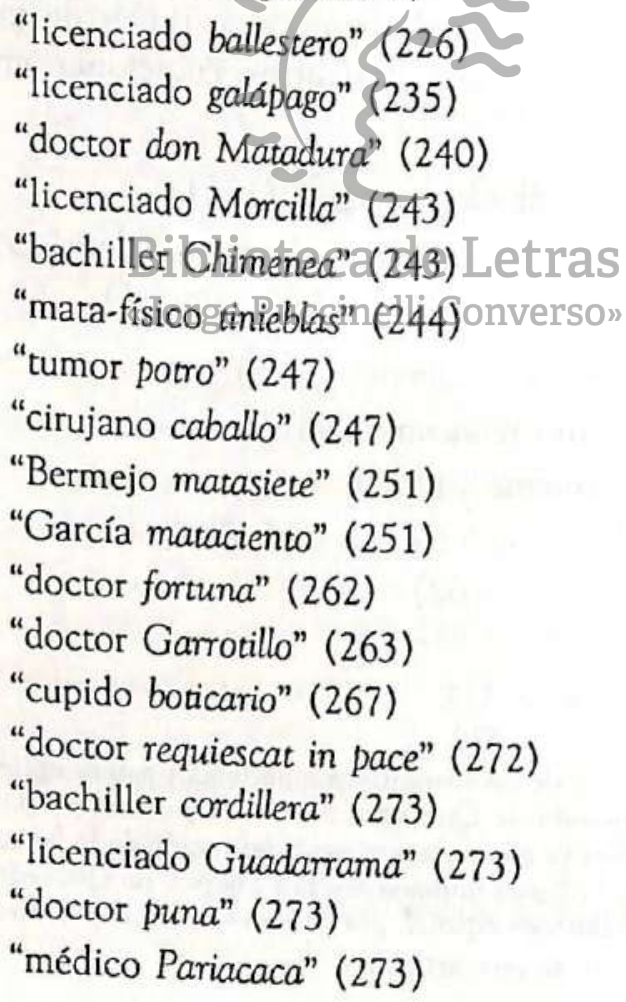




"recetas diciembres" (273)
"turbión albeitar" (273) ${ }^{51}$
"Galeno garrafa" (273)
"nevado Avicena" (274)
"Hipócrates Aura" (274)
"récipes garrapiñas" (274)
"sapo aguachirle" (274)
"curandero rana" (274)

(Los doce últimos casos se refieren a un médico que, entre otras cosas, recetaba "nieve" y "ayudas frescas").

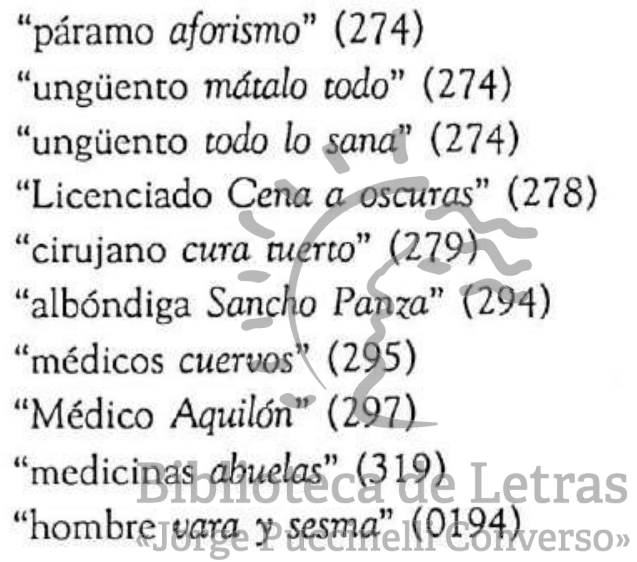

\section{Dilogías}

El uso intencional de una palabra en doble significación dentro de un mismo enunciado, da origen a la dilogía ${ }^{53}$, uno de los recursos del equívoco más favorecidos por el Barroco ${ }^{54}$. Tal tipo de agudeza forma otro juego cerebral. El artificio del ingenio continúa siendo el eje de atención; produce un reparo en el oyente, que debe reflexionar

${ }^{51}$ Albeitar = "s.m. El que cura las enfermedades de las bestias conforme a arte. (...)" Real Academia Española, Diccionario de Autoridades.

${ }^{52}$ Garapiña= "s.f. Las porciones pequeñas de lo líquido, cuando está helado, (...)" Ibidem.

\footnotetext{
${ }^{53}$ Lázaro, Diccionario cit.

${ }^{54}$ Lázaro, Estilo Barroco cit., p. 29.
} 
sobre el discurso, hallar la solución y no olvidarse del virtuoso que forjó la artimaña.

Caviedes posee también, como hombre de ingenio del XVII, un copioso repertorio de dilogías: (subrayamos).

"que las penas que son dichas

dichas son o quieren serlo" (62).

"(...) a nada sabrá el gusto

de quien por boba no sabe" (114)

"Y, en fin, más necia ha de ser

que la otra en su pasión

la fea, pues no ha de hacer,

aunque mude de opinión

que mude de parecer" (115)

"porque con su ayuda pueda

burlarme aqui sin empacho" (117)

(auxilio + lavativa)

"trajeron, para vengarlo,

unos derrotados griegos

que los condujo un fracaso". (126)

(vencidos + desehtrimbad6s). de Letras

[dando "Jor" un "consejo" a un hipócrita]

"En su estilo usará muy cuotidiano

hermanica o hermano,

aunque en tal trato son impropiedades

el que busque un ladrón las hermandades"(129)

(cofradía + institución policial)

[a una hipócrita]

"Arróbese un poquito, que no ignore

que vale el arrobarse mucho oro:" (131)

"en la garganta tenía

puesto un pero por manzana

$y$ era el pero que era hermosa,

tersa pero torneada". (148) 
"Por ser tan delgado el tallo

nunca ballenas gastaba

sino sardinas, (...)" (148)

(cetáceo + "ajustador que traen las mujeres" ${ }^{\text {"55 }}$ )

[refiriéndose al carro de Juno]

"(...) un carro

pavonado como espada,

por ser de pavo las ruedas,

tiros y mulas de pavas", (149)

(Pavonar $=$ "Dar color azulado obscuro al hierro"s6.

"dice que es de lavatorio

devoto, porque es compuesto

de aguapié, (...)" (153)

(agua de lavar pies + "gênero de vino muy bajo"

"De más que pocos cuidados

dá el pie corte, porque hallo

que amor en 10 que aquí callo

parco caminante fué", (184)

(verbo + engrosamienitotdecla piel)Letras

"Seré el doctor Pur Corcobado Converso"

que, con emplastos y apodos,

birla mucho más que todos

porque este mata doblado". (232)

(torcido + doble)

"La piedra filosofal

tienen los curas en ellos;

porque sacan, enterrando,

oro y plata de sus yerros". (262)

\footnotetext{
${ }^{55}$ Dicc. de Autoridades cit.

${ }^{56}$ Ibidem.

${ }^{57}$ Ibidem.
} 
A veces, Caviedes juega con un tercer significado:

"Argos tenía en su cuerpo

más ojos que las labasas

dan a la ropa y que un libro

de partidas anotadas" (150)

En el poema "A una fea" (210), se basa en la palabra "cara": amada + costosa + rostro.

\section{Paronomasias}

En esta figura se consideraba antiguamente "la acumulación de diversas flexiones de una misma palabra y de sus derivados, y también

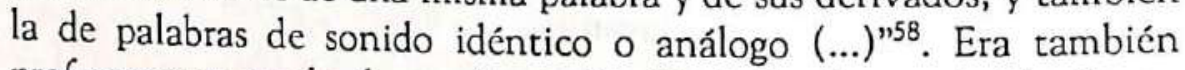
profusamente empleada en el xvir. En Caviedes, la asociación de sonidos parecidos en el verso expone la habilidad del creador, su intencionado manipular los vocablos para desatar el efecto curioso: (Subrayamos)

"dándoos, hermosa, en gracias

lo que no pudo en desgracias"; (33)

El romance amoroso $\mathrm{x}(68)$ acumula derivados deBverböoverca de Letras

"Nada "encuentro, nada miro

que mis pesares divierta

sino el sentirlos, y así

siento que haya quien los sienta" (70)

"y así tengo un querer tal

que no quisiera quererte".(71)

"No la ausencia da olvido

memoria sí, que acuerdan

las ausencias ausentes

que olvidan las presencias". (72)

"Si es remedio el olvidar

y al olvido se dedica.

${ }^{58}$ Curtius, Literatura Europea cit., tomo 1 p. 392. 
el cuidado de olvidar

la acuerda de lo que olvida". (76)

En "Coplas" (78), se juega con: ojos, enojos, hinojos.

"Que sólo sé que no sé,

$y$ aun si el no saber supiera,

ya eso fuera saber algo", (92)

"clavos que son de esclavos y albañiles" (139)

"Lo que el retrato encubría,

colores imaginarias

la retraten, porque desto

mis pinceles se retractan". (148)

"El pelo te he de aplicar

aunque de rabia te peles," (170)

"decimos y redecimos,

y volvemos a decir". (263)

"Venga quien

queriendo, quisiere

dejar de querer". (326)

"El sabeBsǿloisabe ca de Letras

que no es saber, (330)

"porque tus versos son caca,

tus rimas cacofonía". (0137)

\section{Virtuosismo Fonético}

$\mathrm{El}$ ingenio se propone una tarea en la cual la dificultad a resolverse consiste en la aglomeración de determinados rasgos sonoros. Los títulos u otras formas de advertencia, por su parte, anuncian las intenciones virtuosistas del poeta.

Esdrújulos.- Los versos terminados en esdrújulos, de procedencia italiana, se ponen de moda en España a fines del siglo $\mathrm{xvI}^{58 \mathrm{a}}$. En el poema "Al doctor Corcobado. Aviendo salido estos versos respondió

${ }^{58 a}$ Alonso, Góngora y el Polifemo cit., Vol. 1, p. 37. 
a ellos con unas décimas puercas el Dr. Corcobado y unos esdrújulos tan derechos como él. A que se le respondió en los mismos metros" (235 y 046), Caviedes utiliza los finales esdrújulos de los versos con la expresa intención de reflejar en una imagen fónica la joroba del médico, formando una composición gesticulante, un cuasi emblema sonoro. Para Daniel Reedy "it would seem that even the final esdrújulos serve to augment the suggestion and allusion to Dr. Corcobado's deformity by making a jerky abruptness at the end of each verse" ${ }^{159}$. Este "corcobado cántico" -así lo llama Caviedes- es examinado también por Raúl Bueno:

“(...), por el hecho de que la mayor fuerza vocal del octosílabo (y hasta su mayor altura entonativa) se ha trasladado a casi la mitad del verso, en virtud a la palabra esdrújula, y porque su fonema propone una "cadencia" o descendencia musical de la última sílaba, es que tal octosílabo ha adquirido una "engibada" condición acústica:

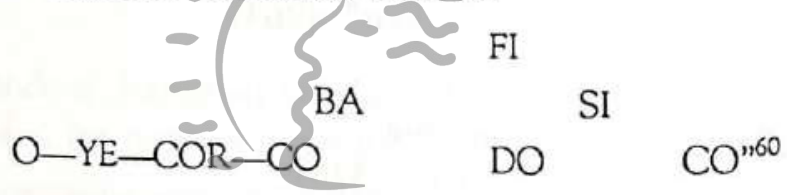

De los esdrújulos terminales que forman este artificioso ejercicio fonético, cinco aúnan a lo sonoro el sentido del vocablo, apretando o reforzando la agudeza en intencionada sobreexpresión: esdrújulos (entiéndase: "corcobados"); galápago ("se alude a caparazón, a espalda de consistencia dura, tiesa y seca; de donde, justo por el doble motivo o por la doble implicancia, debe agregarse esta condición a la espalda"61; cúmulo; obstáculo; túmulo. Tales unidades se generan por hipérbole, $y$, en proceso acumulativo, se produce una hipérbole máxima dada la vertebración del ritmo que asocia a todos los acentos finales en el esdrújulo.

En (210) existe otro poema similar al anterior por sus esdrújulos de fin de verso relacionados con una corcoba.

${ }^{59}$ The poetic art of Juan del Valle Caviedes, p. 73.

60 "Algunas formas del lenguaje satírico de Juan del Valle Caviedes", pp. 349-350.

${ }^{61}$ Ibidem. p. 351. 
El siguiente caso de composición se impone la tarea de diseminar en cada verso una pareja de esdrújulos: "Letanías de dos esdrújulos a María Santísima" (8). Principalmente Caviedes emplea aquí formas de origen latino, cuya fuente hemos de suponerla en las oraciones del culto mariano:
"Oyenos, Paloma humílima, Tórtola que en casto tálamo, cándida esposa y recíproca víctima es al Dios Paráclito. Pláceme, o Aurora fúlgida, nítido lucero, diáfano clásica luna pulquérrima plácido Sol sin obstáculo".(9)

El texto consta de una puta sucesión de vocativos y epítetos en alabanza religiosa. $\mathrm{Al}$ respecto, tratando la enumeración de nombres sagrados, las lista de vocativos, Spitzer dice: "Se procura establecer mediante una serie interminable de sinonimos, una especie de continuidad acústica que tiende a prolongar en el tiempo la expresión de una infinitud"62.

El principio acumylativo del poema al Dr. Corcobado rige aquí también como ejercicio de virtuosismo.

Lengua "aindiada".- La pretensión de imitar la caractrística manera de hablar el castellano que poseen los indígenas, en razón del sustrato quechua, da lugar al juego de ingenio fonético en la versificación ${ }^{62}$. El impulso virtuosista resalta en el paréntesis de los versos siguientes, con el cual propone un cambio de "estilo":

"Y siéndole preguntado

si conocía a los dichos

contrincantes, dijo que:

(mas diré como lo dijo)

qui conoce a otro y a uno,

62 Lingǘstica e Historia cit., p. 313, en nota 20.

${ }^{62}$ Este caso es evidentemente más que un ejemplo de virtuosismo fonético, si atendemos a sus peculiaridades sintácticas y morfológicas y a su importancia para nuestra historia cultural. 
qui son moy señores mios,

el toirto y el señor Vásquez", (283)

Esta intervención del médico indio como testigo es deliberadamente un galimatías, como afirma el poeta en (284). Otros casos: "Al mismo asunto en lengua de indio" (161) y "Por D. Lorenzo, médico indiano" (247).

Yeísmo.- El cambio fonético de "ll" a "y" o viceversa, es motivo de dos poemas en Caviedes, quien busca reproducir acumulativamente el susodicho "embuste": "Retrato de una beldad limense, usando de el común embuste de los patricios de esta ciudad." La habilidad que se trata de lucir consiste en ubicar los términos precisos en fin de verso:

"Como dos luceros beyos

son sus ojos dos estreyas,

mas que el alba hermosas eyas,

mas que el sol briyantes eyos" (195)

"Otro a la misma, usando el trueco de ambos abusos de el fingido embuste" Los finales de verso continúan centralizando la habilidad del virtuoso, ahora en "lleísmos":

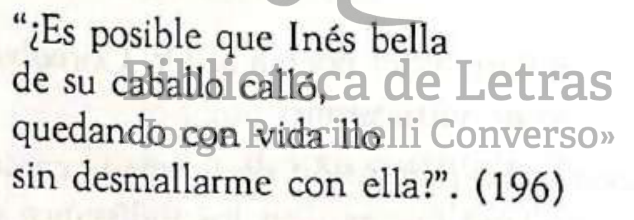

Reedy cita a Rafael Lapesa, en edición de 1959 de su libro Historia de la lengua española (Nueva York; página 320), respecto a Caviedes y el yeísmo: "Rafael Lapesa has noted that Caviedes' works were the first in Spanish America in wich the yeísmo definitely appeared"63.

\section{Juegos con Nombres Propios}

Gracián designa a este tipo de juegos como "agudeza nominal"64. Pueden incluir diversas ingeniosidades, algunas ya tratadas por nosotros.

${ }^{63}$ The poetic art cit., p. 98.
${ }^{64}$ Agudeza cit., Disc. Xxxi. 
Los hemos registrado aparte por constituir un modo preferido por Caviedes.

Dilogías:

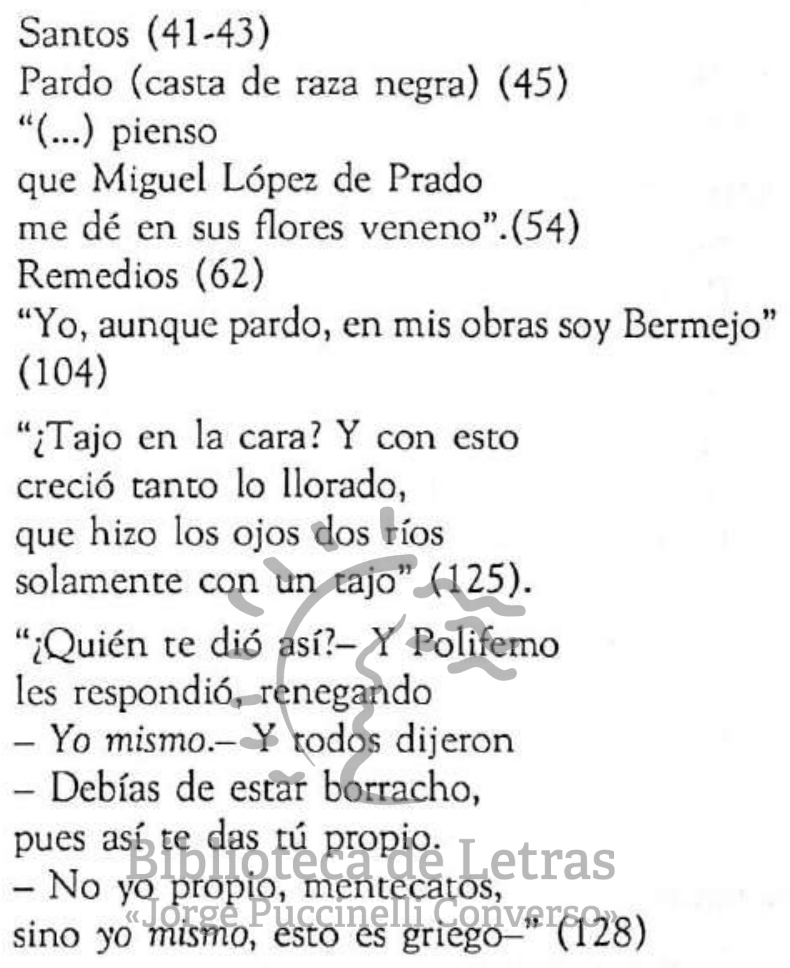

(Se trata pues de la exhumación de una "agudeza" homérica).

Delgadillo (189)

Narciso (flor) (199-302)

"Guerrero en el apellido

trae consigo el matadero;" (228)

"Soldados son menester

donde se halla un doctor Barco,

que puede abordar a un

bajel de vidas cargado?" (251)

"A mi prima machucaste,

Machuca (...)" (261) 
"De su estrella se lamenta

porque en luceros peligra,

si cuanto causó la Venus

con el Mercurio le quitan". (0127)

(El mercurio se usaba como medicina contra la sífilis. Venus, evidentemente, se refiere al amor).

Descomposición del vocablo: (subrayamos)

"voló en el golfo y en el puerto belo (106)

(Portovelo)

"Una gala que tenía" (124)

(Galatea)

"Yánez, pues que ya no es" (240)

"con su boca en Bocanegra" (244)

(se refiere a un mulato)

"se hizo tu fuente rabia" (278)

(Fuenterrabia)

"El alma den (...)" (0128)

(Almaden)

"(...) el escudo Veraguas" (0214)

(se refiere a las zonas íntimas femeninas)

Paronomasias: (Subrayamos) helli Converso"

"y le quede a Pedro piedra" (245)

(juega además con la reminiscencia evangélica).

"Ya, Perico, con mis versos

temo estarás emperrado" (248)

“(...) que Machuca

achaque sus idiotismos" (256)

\section{Poemas "Al mismo asunto"}

El apuntar con varias composiciones a un sólo objetivo se convierte en una prueba más para el ingenio; sirve como demostración de recursos, de poder versificador. Una supuesta inagotabilidad del poeta rastrea la agudeza por la agudeza misma a propósito de un asunto invariable. 
Caviedes dedica 5 poemas "A un corcobado hojalatero que se casó con una mujer muy alta y le dieron en dote unas arrobas de plomo" (159):

"Fementido jorobado

cuyos mentidos amores

son engibados cariños

con que más tu cuerpo dobles"

Luego sigue otro romance "Al mismo asunto de este casamiento" (160), para continuar con un tercero "Al mismo asunto en lengua de indio" (161):

\section{"Balga il diablo Corcobado que osasti también ti casas, sin hallar ganga in so doti sino solo mojiganga".}

El cuarto, "Al mismo asunto en antimados" (162), reitera los conceptos burlones en parejas de versos consonantes. Finalmente, un romance en versos de esdrújulos terminales:

"Mejía, curcuncho acérrimo

se casó con Doña Lánguida, por andat hechtogafapago Letras

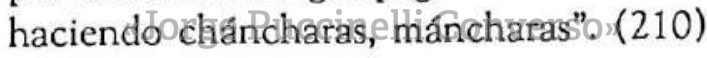

Otro motivo para el ejercicio retórico de Caviedes fue el muelle construido en el Callao por el virrey conde de la Monclova. Le dedica tres sonetos de intenciones panegíricas y cultas: 102-103.

Un ejemplo más lo hallamos en dos sonetos que tienen el capricho de tratar el tema común en su aspecto serio y en el humorístico, respectivamente: "Razón porque los pobres son capaces y los ricos torpes" (101) y Otro al mismo asunto. Jocoso" (101).

Los poemas sobre yeísmo también pueden asimilarse como ejemplo de composiciones "al mismo asunto".

Estamos, pues, ante un brote del "nihilismo temático" observado por Díaz-Plaja en el Barroco: 
“(...) nihilismo temático en que se debate el poeta falto de los grandes motivos vitales -el amor y la guerra- que le legó el Renacimiento. Su temática será, pues, mínima o inexistente; bastará con que sirva de pretexto a la habilidad poética, al grupo de recursos retóricos que quiera poner en juego" ${ }^{165}$

\section{Disociación}

La descomposición de los vocablos para crear, con las sílabas reagrupadas arbitariamente, un sentido diverso, señala un factor más de los afanes virtuosistas en Caviedes. De los nombres propios que resultan sufriendo el juego disociativo nos ocupamos anteriormente. Aquí exponemos algunas nuevas realizaciones pretendidamente ingeniosas: (subrayamos)

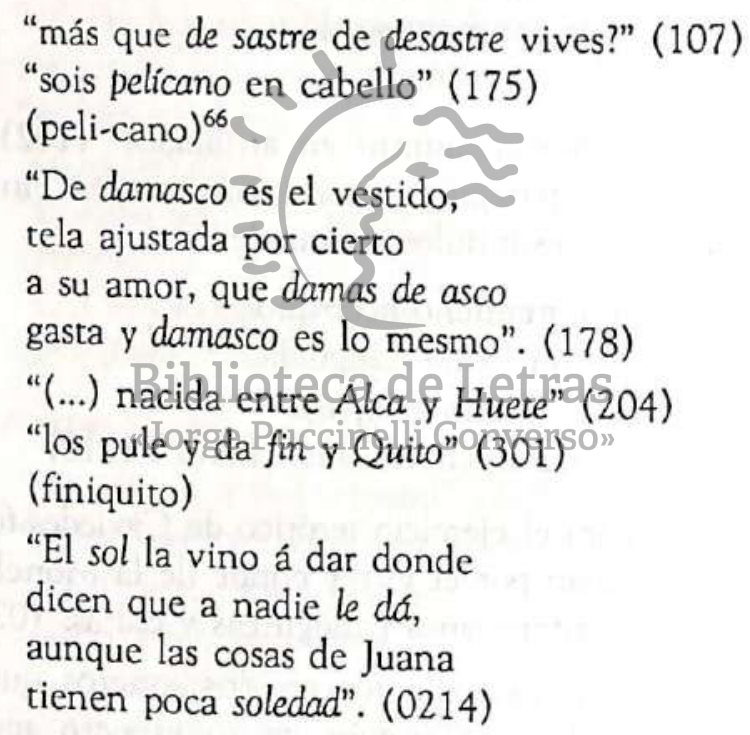

\section{Frases hechas}

Introducir frases hechas en los versos da ocasión a juegos de ingenio. Cumplen también el requisito de la dificultad a superar. Un buen grupo reune el tipo de frases proverbiales y sinsentidos: (subrayamos)

${ }^{65}$ La Poesía Lírica Española, p. 170.

${ }^{66}$ Juego usado por Góngora en una de sus sátiras. Lázaro, Estilo Barroco cit., p. 54. 
"Andar quiero por los troncos

contándoles mi desgracia,

como si contarlas a ellos

fuera andarse por las ramas". (69)

"bobo de coria en simpleza" (83)

"Perico es de estos palotes

y aunque periquitos le echan,

cuenta todo de pe a pa,

al pie de su inculta letra". (83)

"todo paja, nada grano,

cascos vanos, tripas huecas,

mucho ruido, pocas nueces,

muchos dones, pocas rentas".(92)

"Por no andar a mojicones

se fueron, y lo dejaron

dado a un millón de demonios

porque pudieran cargarlo" (128)

(se refiere a Polifemo)

"que alla van leyes donde quieren reyes" (139)

"Ignorantelparecíaca de Letras

quando "estáseiendoinanlialhająr.so"

que el que lo es se hace ojos,

admirándose sin causa". (150)

(se trata de Argos y sus muchos ojos)

"(Mercurio) se disfrazó de Pastor

con zurrón y con abarcas

y a ojos vistas de tantos

vino el astuto (...)" (151)

(otra vez sobre Argos)

"En pruebas del rey Perico

jurasteis que era viznieto

del rey que rabió, (...)" (176) 
"De doña Maricastaña

fuisteis también escudero" (176)

"Vivid más que ¡Vive cribas!

que en la boca de los necios

há dos mil años que vive,

edades de juramentos". (177)

"Ay! con todos los demonios!

dijo Lucifer, cayendo", (187)

"una cura que hizo, a Dios

que te la depare buena;

finalmente él acertó,

sea por fás o por nefas,

y así merece una fama

de haldas o de mangas hechas". (245)

"Doctor de tápalo todo

no inventó Pedro Urdemalas" (271)

"Oy de Alcalde sale Amor

ya que dice el vulgo necio

que $a$ troche moche ejecuto

y a roso y belloso prendo". (323)

"Si el ojo del amo engorda

al caballor, qué rollizas

estarán tus coplas si

tú con tu ojo las miras". (0138)

(El sentido de este concepto, como podrá comprobarse en el poema completo, es sumamente grotesco).

"Escrúpulo de maridos,

o si es no es de los casados", (0193)

Caviedes se burla de estas fórmulas populares, con lo que manifiesta una tendencia a superar la trivialidad del lenguaje común. Aquí también Quevedo ha indicado el camino, en su "Sueño de la muerte".

Para otros casos: 40-85-121-139-164, etc. 
Una clase distinta de frases hechas las encuentra el poeta en los títulos de obras literarias, sobre todo comedias. Hay, por ejemplo, una composición religiosa construída ex profeso coordinando títulos: "A María Santísima, empieza y acaba con título de comedia" (20):

"La más constante mujer"

"triunfos de amor y fortuna"

"el Burlador por su culpa".

Y en la sátira "A una dama que rodó del cerro de San Cristóbal": (subrayamos)

"Por incitar su caída

mucha tentación carnal

fué su desgracia en comedia,

caer para levantar". (0214)

(Concepto "en comedia", de implicancias nada sutiles)

\section{Juegos con traducciones}

El autor usa las formas latinas de circulación popular, como fuente para sus artificios, en los cuales la traducción da funcionamiento al concepto: (subrayamps) blioteca de Letras

"Ambiciōsogel Rüutgonavairo,pnverso"

todo bastimento, en fin,

con desvergüenza y descaro,

hízole carne en latín,

si todo en Lima era caro". (41)

(lat. caro, carnis $=$ carne. Se trata de una dilogía que mira a dos lenguas).

"Las columnas del non plus

eran piernas, y quitando

el non, proseguían, más

las Indias de lo tapado". (120)

(Aquí se produce un juego disociativo en los elementos latinos, uno de ellos traducido). 
"El tintero es de los viejos

torcido nemine parco,

pues a ninguno perdona

este cornudo epitafio".(0194)

(nemine parco $=$ a nadie perdono. Se pone en juego la traducción, la diferencia fonética y la redundancia de sentido).

En la composición "La salve glosada para la natividad de María Santísima", Caviedes entremezcla artificiosamente términos latinos y castellanos:

"Et Jesum benedictum,

León de tribu inmutable,

que fructum ventris tui,

ya cordero humanastes,

nobis post hoc exilium

ostende, eja, inefable

prenda de inmenso precio" (16)

15. Juegos con términos gramaticales ${ }^{67}$

Caviedes posee unas Redondillas ortográficas" (116), cuyo aritificio radica en la susțitución de fragmentos de verso por denominaciones gramaticátes. Basta la "tracucción", elementalmente orientada por la rima arel metro, para resolver el "problema":

"no es cosa de ...! (admiración)

"yo disiento de ese ." (punto)

"sí de ..." (puntos suspensivos)

una dilogía:

"y con su pan se lo," (coma)

"De aquestas aves le diera

un regalo al doctorcito,

porque ponga punto y coma

en su latín de idiotismo". (0131)

(Las aves a comerse constituyen una burda alusión fisiológica).

${ }^{67}$ Curtius indica la procedencia antigua y medieval de este recurso del siglo XVII español. Literatura Europea cit., Tomo II, p. 591 y ss. 


\section{Acumulación}

Un nuevo modo de virtuosismo se genera como principio de composición en Caviedes: la acumulación de elementos. Este procedimiento da lugar ejercicio del ingenio por unidades cerradas, cuya sucesión, para constituirse en totalidad, requiere un soporte mínimo temático, argumental, o puramente intencional. En un poema como "Narciso y Eco", la línea narrativa es sólo el pretexto para el engarce de ingeniosidades. En otros casos basta el propósito del poeta para adjudicar cierta unidad a sus aglomeraciones de agudezas. Se trata, principalmente, de ocosar un objetivo a través de la proliferación de conceptos basados en un núcleo común, para exhibir la propia capacidad creadora. Por ejemplo, con motivo de una nariz desproporcionada, las agudezas se multiplican teniendo este solo núcleo como eje. El poeta se somete a prueba en las variaciones sobre lo único, explotando la inagotable capacidad correlacionante de los objetos.

Generalmente sus conceptos van contenidos en versos esticomíticos; en coplas, tratándose de romances; en cada cuarteto y terceto, para los sonetos; ete. Sendas explicaciones suelen integrarse en los diversos conceptos, (o como diría Gracián, "resuelve el reparo"). Usa para esto ciertas partículas-conjuntivas: causales (porque, cuando, como, pueş que, puesta que, aunque); condicionales (si, como). Pocas veces explica sin emplear conjunciones.

Procederemos a dar una relación sucinta de los casos más interesantes de acumulación en Caviedes:

Enumeración de antítesis:

"Vos, el Todopoderoso,

yo el todo pobre e inicuo.

Vos el sumamente sabio,

yo el sumamente imperito". etc. (6)

(ver: 27)

Esdrújulos (8-210-046)

Conceptos sobre ingenio (32)

Conceptos en "metáfora de astrología" (45)

Conceptos sobre partes del cuerpo (49-147) 
Conceptos comparando partes del cuerpo con médicos (53).

"Definiciones" (94-95)

Términos "caballerescos" (96-135)

Conceptos sobre gigantismo (117)

Epítetos a los demonios (132)

Enumeración de héroes (136)

Conceptos sobre "borracho" (146-153-154-157)

Conceptos sobre los muchos ojos de Argos (150)

Conceptos sobre pobreza de vestido (156)

Conceptos sobre joroba (159-160-161-162-210-276-046).

Conceptos sobre mulatos (163)

Conceptos en "metáfora de guerra" (169)

Conceptos sobre edad avanzada (175)

Conceptos sobre "negro" (178)

Conceptos sobre "vieja" (179)

Conceptos sobre "nuevas leyes en el amor" (181)

Conceptos sobre "pies ajustados" (184)

Conceptos sobre "diablos de profesionales" (187)

Conceptos sobre delgadez (189)

"Yeísmos" y "Tleísmos" (195-196)

Conceptos sobre "ilusión de Narciso" (197)

"Privilegios del pobre"(211)

"Erratas" (213)

Epítetos a médicos (223)

Conceptos sobre "armas-curaciones" (224)

Conceptos sobre "muerte-y -médicos" (226)

Apodos sobre "negro" (243)

Conceptos sobre "barcos de guerra-médicos" (251)

Conceptos sobre "médicos-frutos" (257)

Conceptos sobre "médico tuerto" (268)

Apodos sobre "frío" (273)

"Apodos de sabandija" a un jorobado (276) 
Conceptos sobre curar cataratas (297)

Conceptos sobre "médicos ajusticiamientos" (306)

Citas de autoridades y ejemplos acerca de los médicos (315)

Conceptos sobre "presos de amor" (323)

Conceptos sobre enfermedad venérea (0126-0134)

Debemos mencionar, por otra parte, las agrupaciones de poemas a un mismo asunto, que ya han sido tratadas.

Así como en cada poema la acumulación funciona con el carácter de principio compositivo, el "Diente del Parnaso" se rige, en su conjunto, también por dicho principio. Esta colección de poemas antimedicales se halla constituida como una parodia del libro impreso. Incluye satíricamente estereotipos de las ediciones contemporáneas: epígrafes; "Copla del autor"; "Fe de erratas"; "Tasa"; "Licencia"; "Privilegio"; "Prólogo"; "Parecer que da de esta obra..."; "Dedicatoria". El propósito acumulativo del libro queda indicado en la "Tasa". (subrayamos)

\section{"Este libro está tasado por los malsines de ingenio, a cien simples adiciones por cadapuno de su pliegos". (213 ths}

Con lo cual el "Diente delcparnason pretende ser entregado al dominio de la ingeniosidad, sin intención de ser una obra concluida. Su peculiaridad consiste pues en carecer de límites. Al estimular la edición por mano ajena se acentúa la condición no impresa del libro y su engrosamiento por circulación. Detrás de todo esto se encuentra el virtuoso que reta al ingenio de los otros. 


\section{BIBLIOGRAFIA CITADA}

Alonso, Dámaso

1950 La lengua poética de Góngora. Madrid, Consejo Superior de Invest. Cient..

1961 Góngora y el Polifemo. Madrid, Gredos.

1962 Poesía Española. Madrid, Gredos.

Bueno Chávez, Raúl

1972 "Algunas formas del lenguaje satírico de Juan del Valle Caviedes". En: Literatura de la Emancipación Hispanoamericana y otros ensayos. Lima, Universidad Nacional Mayor de San Marcos, 339-345.

Casalduero, Joaquín

1962 Estudios sobre el teatro español. Madrid, Gredos.

Cossío, José María de

1952 Fábulas mitológicas en España. Madrid, Espasa-Calpe.

Curtius, Ernst Robert

1955 Literatura Europea y Edad Media latina. México, F.C.E.

Cvitanovic, DinkoJyotrosuccinelli Converso»

1969 El sueño y su representación en el Barroco español. Bahía Blanca, Universidad Nacional del Sur.

Díaz-Plaja, Guillermo

1937

1948

La poesía lírica española. Barcelona, Labor.

Hacia un concepto de la literatura española. Buenos Aires, Espasa-Calpe.

DiltheY, Wilhelm

1944

Hombre y mundo en los siglos xVI y xVII. México, F.C.E.

Graclán, Baltazar

1942

Agudeza y arte de ingenio. Buenos Aires, Espasa-Calpe. 
GutiérReZ, Juan María

1957 Escritores Coloniales Americanos. Buenos Aires, Raygal. Hauser, Arnold

1965 El manierismo- Crisis de Renacimiento y origen del arte modemo. Madrid, Guadarrama.

Hocke, Gustav Rene

1961 El manierismo en el arte europeo. Madrid, Guadarrama.

LAPESA, Rafael

$1950 \quad$ Historia de la lengua española. Madrid, Escelicer.

Lázaro Carreter, Fernando

1962 Diccionario de términos filológicos. Madrid, Gredos.

1966 Estilo barroco y personalidad creadora. Salamanca, Anaya.

Pfandl, Ludwig

1933 Historia de la literatura nacional española en la Edad de Oro. Barcelona, Sucesores de Juan Gili.

Real Academia Española

1963 Diccionarib dei Autonidades. Madrid, Gredos.

REEDY, Daniel R.

1964 The poetic art of Juan del Valle Caviedes. Chapel Hill, The University of North Carolina Press.

SÁNCHEZ, Luis Alberto

1965 La literatura peruana. Lima, Ediventas, tomo II.

SPITZER, Leo

1955 Lingǘstica e historia literaria. Madrid, Gredos.

VOSSLER, Karl

1933 Lope de Vega y su tiempo. Madrid, Revista de Occidente.

1934 Introducción a la literatura española del siglo de oro. Madrid, Cruz y Raya. 
1941 La soledad en la poesía española del siglo de oro. Madrid, Revista de occidente.

1947 Escritores y poetas de España. Buenos Aires, Espasa-Calpe.

Ediciones de Juan del Valle y Caviedes consultadas

Odriozola, Manuel de

1873 Documentos literarios del Perú. Imprenta del Estado, tomo V.

ReEDY, Daniel R.

1963 "Poesías inéditas de Juan del Valle Caviedes". En: Revista Iberoamericana. México, Vol. xxix, N 55, pp. 157-190.

Valle y Caviedes, Juan del

1984 Obra completa. Edición, prólogo, notas y cronología de Daniel R. Reedy. Biblioteca Ayacucho, 107 (Caracas). Barcelona, Bodoni.

Valle y Caviedes, Juan del

1990 Obra completa. Édición de María Leticia Cáceres, A. C.

I. Estudios de Luis Jaime Gisneros ${ }_{3}$ Guillermo Lohmann Villena. Lima, Banco de Crédito del Perú.

Vargas Ugarte, Rubén

1947 Obras de Don Juan del Valle y Caviedes. Lima, Tipografía Peruana. (Clásicos Peruanos - Vol. 1). 